\title{
Těžké minerály rozsypových ložisek zlata vázaných na khantaishirský ofiolitový komplex pobliž měst Altaj a Khaliun (jihozápadní Mongolsko)
}

The heavy-minerals gold placer deposits spatially related to the Khantaishir ophiolitic complex near the Altai and Khaliun towns (Southwestern Mongolia)

\author{
David Buriánek ${ }^{1,2} \rightrightarrows$, Jiř́i Svatuška² \\ ${ }^{1}$ Česká geologická služba, Leitnerova 22, 60200 Brno \\ 2Ústav geologických věd PřF MU, Kotlářská 2, 61137 Brno
}

Key words:

Heavy minerals, gold, placer deposits, transportation, Southwestern Mongolia

$\Xi$ david.burianek@geology.cz

Editor:

Martin Ivanov

\begin{abstract}
Detailed morphological and chemical studies of heavy minerals from fluvial sediments of two localities in the area of the Khantaishir ophiolitic complex near the Altai and Khaliun towns (Southwestern Mongolia) allowed the interpretation of possible source region for the gold. The heavy mineral spectrum from the sediments near the Altai town is dominated by magnetite (32\%), chromite (27\%), epidote (11\%), apatite (6\%), and clinopyroxene (5\%). We assume that these minerals come from the ultrabasic and basic igneous rocks in the Neoproterozoic Khantaishir ophiolitic complex. The relatively undeformed and threedimensional shape of gold particles indicate a short distance of their transport. The native gold is rare enclosed in dolomite or quartz, which indicates that potential gold sources are listvenite. The heavy mineral spectrum from the fluvial sediments in the small creek near the Khaliun town is different. The studied sample includes magnetite (31\%), amphibole (19\%), zircon (18\%), pyrite (13\%), apatite (5\%), epidote (4\%), titanite (4\%), clinopyroxene (2\%), monazite (1\%), ilmenite (1\%), garnet (1\%), and barite (0.1\%). Large variations in the mineral composition of heavy mineral spectrum indicate a wide source area which includes basic to intermediate igneous rocks of Cambrian-Ordovician Ikh-Mongol Arc System and medium-grade metamorphic rocks (metapelite). The subspherical rounded shape of the gold particles indicates fluvial transport. In the case of small and geologically simple drainage area as creek near the Altai town, heavy minerals represent a good tool for determination of the origin of placer gold. There is a contrast between the heavy mineral spectrum from the localities near the Altai and Khaliun towns. The shape of gold particles as well as a simple heavy mineral spectrum from sediments near the Altai indicates short transport from the limited draining area (approximately $6 \mathrm{~km}^{2}$ ). Gold probably originate from the ultramafic rocks (listvenite), according to associated dolomite and simple spectrum of heavy minerals. The origin of gold from the placer deposits near Khalinun remains unclear and most probably could originate from the hydrothermal veins in intermediate or basic igneous rocks (presence of barite associated with abundant pyrite).
\end{abstract}

\section{Úvod}

V průběhu posledních dvaceti let došlo $\mathrm{v}$ Mongolsku $\mathrm{k}$ výraznému nárůstu nelegální těžby zlata. Dobře patrným projevem této činnosti jsou rozsáhlé pinky a odvaly v okolí mnoha stálých i občasných říčních toků na celé řadě míst Mongolska. Díky této aktivitě se mění morfologie krajiny a často je také ohroženo životní prostředí. Pro geology však tato činnost skýtá možnost detailně prozkoumat zlatonosné vrstvy, které jsou často lokalizovány pouze na bázi říčních sedimentů (bedrock). Tyto vrstvy jsou totiž většinou překryty několika metry klastických sedimentů, které mnohdy žádné zlato neobsahují. 


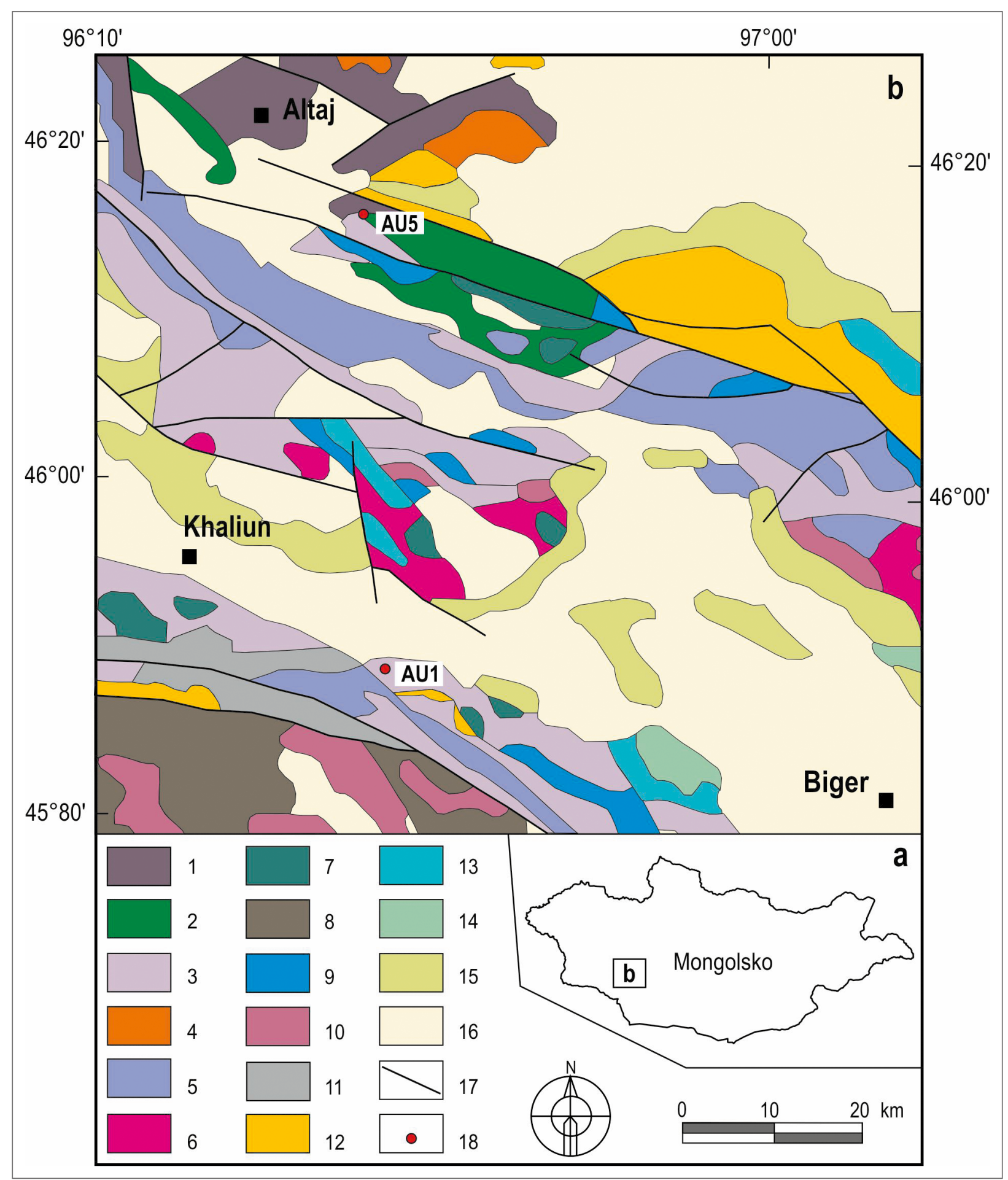

Obr. 1: Zjednodušená geologická mapa jz. Mongolska a pozicí studovaných vzorků (upraveno podle Zabotkin 1988; Matsumoto, Tomurtogoo 2003; Gianola et al. 2019): 1 - metamorfované horniny; 2 - ultrabazické horniny; 3 - neoproterozoické až kambrické sedimenty; 4 - proterozoické granitoidy; 5 - kambrické sedimenty a vulkanity; 6 - kambrické tonality až granodiority; 7 kambrická gabra a diority; 8 - ordovické až kambrické sedimenty (tugrugské souvrství); 9 - devonské sedimenty; 10 - karbonské až devonské granitoidy; 11 - karbonské sedimenty; 12 - permské sedimenty; 13 - jurské sedimenty; 14 - křídové sedimenty; 15 - paleogenní a neogenní sedimenty; 16 - kvartérní sedimenty; 17 - zlomy; 18 - místa odběru vzorků.

Fig. 1: Simplified geological map of SW Mongolia with location of the study samples (Zabotkin 1988; Matsumoto, Tomurtogoo 2003; Gianola et al. 2019): 1- metamorphic rocks; 2 - ultrabasic rocks; 3 Neoproterozoic to Cambrian sediments; 4 - Proterozoic granitoids; 5 - Cambrian sediments and volcanics; 6 - Cambrian tonalities to granodiorites; 7 - Cambrian gabbro and diorites; 8 - Ordovician to Cambrian sediments (Tugrug Formation); 9 - Devonian sediments; 10 - Carboniferous to Devonian granitoids; 12 - Carboniferous sediments; 11- Permian sediments; 13 - Jurassic sediments; 14 - Cretaceous sediments; 15- Paleogene and Neogene sediments; 16 - Quaternary sediments; 17 - faults; 18 - sampling points. 
Výzkum zlatonosných vrstev může významně přispět k identifikaci primárních zdrojů zlata a umožnuje hlouběji porozumět dynamice transportu fluviálních sedimentů $\mathrm{v}$ aridních oblastech. Cílem tohoto příspěvku je srovnat dva geneticky podobné výskyty zlata prostorově svázané s khantaishirským ofiolitovým komplexem. K tomuto účelu bylo využito těžkých minerálů, jejichž morfologie, procentuální zastoupení v sedimentu, stejně tak jako jejich chemické složení mohou pomoci při identifikaci zdrojových hornin zlata (např. Morton, Hallsworth 1994).

\section{Geologie studované oblasti}

Neoproterozoickýkhantaishirský ofiolit poblíž měst Altaj a Khaliun byl interpretován jako sekvence hornin typických pro oceánskou kůru a svrchní plášt. Vystupují zde tělesa harzburgitů, dunitů, pyroxenitů, zvrstvených a izotropních gaber (většinou tholeitických). Jsou zde také bazické žíly (tholeitické a vápenato-alkalické), polštářové lávy a hlubokomořské sedimentární rohovce (Zonenshain, Kuzmin 1978; Matsumoto, Tomurtogoo 2003). Většina těchto hornin je postižena velmi slabou metamorfózou maximálně dosahující facie zelených břidlic. Zmíněný vulkanosedimentární komplex je pak místy intrudován magmatickými horninami souvisejícími s vývojem kambro-ordovického aktivního kontinentálního okraje mikrokontinentu Baydrag (vulkanický oblouk Ikh-Mongol, Janoušek et al. 2018). Dominantními magmatickými horninami jsou amfibol-biotitické tonality až gabra a amfibol-pyroxenické křemenné diority, amfibolická gabra a pyroxenity místy s olivínem. Společně s magmatickými horninami se v této oblasti vyskytují kambro-ordovické slabě metamorfované vulkanosedimentární komplexy (například Narran a Ulaanshand) a deformované silurské až devonské vulkanosedimentární komplexy (Hanžl et al. 2019). Lokálně zde vystupují permské vulkanity a sedimenty. Část studovaného území je také pokrytá mezozoickými a kenozoickými sedimenty (obr. 1; Zabotkin 1988; Matsumoto, Tomurtogoo 2003; Gianola et al. 2019).

Studované vzorky těžkých minerálů pocházejí ze dvou lokalit situovaných v jz. části Mongolska. Jedná se o pozůstatky po neoficiální těžbě zlata jv. od městečka Khaliun (AU1) a j. od města Altaj (AU5).

Lokalita, odkud pochází vzorek AU1 (4549`04.6“N; $\left.96^{\circ} 26^{\prime} 12.2^{\prime \prime} \mathrm{E}\right)$, je situována na úpatí horského hřbetu jv. od městečka Khaliun. Zmíněný horský hřbet je budován neoproterozoickými serpentinity, chloritickými břidlicemi, vápenci a zelenými břidlicemi. Lokálně zde vystupují sedimenty významnějšího říčního toku, který dnes protéká vedlejším údolím. Tento tok drénuje území o rozloze několika desítek $\mathrm{km}^{2}$ tvořené ultramafickými horninami a kambro-ordovickými vyvřelými a metamorfovanými horninami. Těžba probíhala $\mathrm{v}$ korytech občasných drobných toků transportujících materiál z blízkého horského hřbetu a staré říční terasy ve výšce několik desítek metrů nad dnešní úrovní toku výše zmíněné řeky.

Lokalita u města Altaj (AU5) je situována v říčních sedimentech na s. úbočí horského hřbetu $\left(46^{\circ} 15^{\prime} 46.7^{\prime \prime} \mathrm{N}\right.$ $\left.96^{\circ} 25^{`} 00.8^{\prime \prime} \mathrm{E}\right)$, který je budován hlavně serpentinity, gabry, bazalty a vápenci. $\mathrm{V}$ malém množství jsou zastoupeny
Tab. 1. Poměrné zastoupení těžkých minerálů v sedimentech z lokality AU1 a AU5, velikost zrn 0,2-0,5 mm. Č́sla v tabulce představují počet zrn na 100 (\%).

Tab. 1. Abundance of heavy minerals in black sands, the grain-size is $0.2-0.5 \mathrm{~mm}$. The numbers in table constitute quantity (\%).

\begin{tabular}{|l|r|r|}
\hline těžké minerály & AU1 & AU5 \\
\hline Amfibol & 19,2 & 0,5 \\
\hline Apatit & 5,3 & 6,8 \\
\hline Baryt & 0,1 & 0,0 \\
\hline Epidot & 3,9 & 10,8 \\
\hline Granát & 1,1 & 0,0 \\
\hline Horniny & 0,0 & 11,3 \\
\hline Chromit & 0,7 & 27,3 \\
\hline Ilmenit & 1,1 & 0,5 \\
\hline Magnetit & 30,9 & 32,4 \\
\hline Monazit & 1,3 & 0,3 \\
\hline Pyrit & 12,6 & 2,5 \\
\hline Pyroxen & 1,5 & 4,9 \\
\hline Titanit & 3,7 & 0,0 \\
\hline Zirkon & 18,4 & 2,6 \\
\hline
\end{tabular}

slabě metamorfované břidlice a tufity. Poblíž studované lokality, také vystupují metamorfované horniny (hlavně ruly méně amfibolity) náležející k mikrokontinentu Dzabkhan. Tento tok také eroduje starší výplavové kužely.

\section{Metodika}

Těžké minerály byly získány rýžováním. Materiál byl nejprve zbaven hrubší frakce (valounů nad $2 \mathrm{~cm}$ ) a vodou se odkalila nejjemnější frakce (jíl a prach). Lehký písčitý podíl byl odstraněn pomocí rýžovací pánve. Těžký podíl byl zabalen a odeslán do České republiky k dalšímu zpracování. V laboratoři byla zpracována celá těžká frakce, získaná z 15 (AU5) a 22 (AU1) kg sedimentu. Asociace dvou vzorků těžkých minerálů byly studovány pomocí binokulárního mikroskopu Nikon SMZ 1500. Jednotlivé minerály jsou určeny na základě tvaru, barvy, štěpnosti a dalších optických vlastností (např. index lomu ve vodní imerzi v polarizovaném světle, Rost 1956). V každém vzorku bylo vyhodnoceno 300 minerálních zrn (tab. 1). Pro určení podílu magnetitu byl použit permanentní magnet.

Chemické složení vybraných minerálů bylo analyzováno pomocí elektronové mikrosondy Cameca SX-100 (operátor P. Gadas) na Pracovišti elektronové mikroskopie a mikroanalýzy (Společné pracoviště Ústavu geologických věd PřF MU a České geologické služby). Měření probíhalo ve vlnově disperzním módu za následujících podmínek: urychlovací napětí $15 \mathrm{kV}$, průměr elektronového svazku $5 \mu \mathrm{m}$, proud $30 \mathrm{nA}$, načítací čas 20 sekund. Jako standardu bylo užito (Ka X-ray linie): augit ( $\mathrm{Si}, \mathrm{Mg}$ ), ortoklas $(\mathrm{K})$, jadeit $(\mathrm{Na})$, chromit $(\mathrm{Cr})$, almandin $(\mathrm{Al})$, andradit $(\mathrm{Fe}$, $\mathrm{Ca})$, rodonit $(\mathrm{Mn}), \mathrm{TiO}(\mathrm{Ti})$. Krystalochemický vzorec amfibolu byl v souladu s platnou klasifikací Hawthorna et al. (2012) normalizován metodami Si-Ca\&Li $=15$ a $\mathrm{Si}-\mathrm{Mg} \& \mathrm{Li}=13$. Krystalochemický vzorec epidotu byl vypočten na 12,5 aniontů, ilmenit na 6 kyslíků, spinelidy na 4 kyslíky a pyroxeny na 6 kyslíků přičemž $\mathrm{Fe}^{3+}$ bylo dopočteno podle Droopa (1987). Minerály byly přepočteny programem Microsoft Excel. Reprezentativní chemické složení pyroxenu a epidotu je uvedeno v tabulkách 2 a 3. 
Tab. 2: Chemické složení pyroxenu ve vzorcích AU1 a AU5.

Tab. 2: Chemical composition of pyroxene from samples AU1 and AU5.

\begin{tabular}{|l|r|r|r|r|r|r|}
\hline Analýza & $\mathbf{1 1 4}$ & $\mathbf{9 8}$ & $\mathbf{9 9}$ & $\mathbf{1 0 4}$ & $\mathbf{1 0 5}$ & $\mathbf{1 0 0}$ \\
\hline $\mathrm{Vzorek}$ & $\mathrm{AU} 1$ & AU5 & AU5 & AU5 & AU5 & AU5 \\
\hline $\mathrm{SiO}_{2}$ & 54,07 & 53,92 & 54,94 & 55,20 & 57,02 & 55,24 \\
\hline $\mathrm{TiO}_{2}$ & 0,32 & 0,54 & 0,04 & 0,09 & 0,05 & 0,01 \\
\hline $\mathrm{Al}_{2} \mathrm{O}_{3}$ & 1,30 & 3,56 & 2,63 & 2,84 & 1,31 & 1,22 \\
\hline $\mathrm{Cr}_{2} \mathrm{O}_{3}$ & 0,18 & 0,47 & 0,19 & 0,49 & 0,46 & 0,69 \\
\hline $\mathrm{Fe}_{2} \mathrm{O}_{3}$ & 2,35 & 0,00 & 0,00 & 0,00 & 0,00 & 0,45 \\
\hline $\mathrm{FeO}$ & 2,27 & 9,69 & 5,34 & 7,51 & 6,25 & 2,37 \\
\hline $\mathrm{MnO}$ & 0,13 & 0,15 & 0,11 & 0,14 & 0,25 & 0,07 \\
\hline $\mathrm{MgO}$ & 17,10 & 17,89 & 20,27 & 19,74 & 19,98 & 17,62 \\
\hline $\mathrm{CaO}$ & 23,51 & 12,48 & 14,25 & 12,51 & 13,31 & 24,69 \\
\hline $\mathrm{Na} 2 \mathrm{O}$ & 0,42 & 0,67 & 0,24 & 0,51 & 0,14 & 0,11 \\
\hline $\mathrm{K} 2 \mathrm{O}$ & 0,00 & 0,21 & 0,00 & 0,04 & 0,00 & 0,03 \\
\hline $\mathrm{Celkem}$ & 101,64 & 99,57 & 98,01 & 99,06 & 98,77 & 102,50 \\
\hline $\mathrm{Si}$ & 1,944 & 1,984 & 2,021 & 2,021 & 2,098 & 1,963 \\
\hline $\mathrm{Al}$ & 0,055 & 0,155 & 0,114 & 0,122 & 0,057 & 0,051 \\
\hline $\mathrm{Fe}{ }^{3+}$ & 0,064 & 0,000 & 0,000 & 0,000 & 0,000 & 0,012 \\
\hline $\mathrm{Cr}$ & 0,005 & 0,014 & 0,005 & 0,014 & 0,013 & 0,019 \\
\hline $\mathrm{Ti}$ & 0,009 & 0,015 & 0,001 & 0,002 & 0,001 & 0,000 \\
\hline $\mathrm{Fe}{ }^{2+}$ & 0,068 & 0,298 & 0,164 & 0,230 & 0,192 & 0,070 \\
\hline $\mathrm{Mn}$ & 0,004 & 0,005 & 0,003 & 0,004 & 0,008 & 0,002 \\
\hline $\mathrm{Mg}$ & 0,917 & 0,981 & 1,112 & 1,077 & 1,096 & 0,933 \\
\hline $\mathrm{Ca}$ & 0,905 & 0,492 & 0,562 & 0,491 & 0,525 & 0,940 \\
\hline $\mathrm{Na}$ & 0,029 & 0,048 & 0,017 & 0,036 & 0,010 & 0,007 \\
\hline $\mathrm{K}$ & 0,000 & 0,010 & 0,000 & 0,002 & 0,000 & 0,001 \\
\hline $\mathrm{Celkem}$ & 4,000 & 4,000 & 4,000 & 4,000 & 4,000 & 4,000 \\
\hline $\mathrm{Wo}$ & 46 & 27 & 30 & 27 & 29 & 48 \\
\hline $\mathrm{En}$ & 46 & 54 & 60 & 59 & 60 & 47 \\
\hline $\mathrm{Fs}$ & 7 & 17 & 9 & 13 & 11 & 4 \\
\hline $\mathrm{Ac}$ & 1 & 3 & 1 & 2 & 1 & 0 \\
\hline & & & & & & \\
\hline
\end{tabular}

Tab. 3: Chemické složení minerálů skupiny epidotu ve vzorcích AU1 a AU5. Tab. 3: Chemical composition of minerals of the epidote group from samples AU1 and AU5.

\begin{tabular}{|l|r|r|r|r|r|}
\hline analýza & $\mathbf{1 1 0}$ & $\mathbf{9 6}$ & $\mathbf{9 7}$ & $\mathbf{1 0 1}$ & $\mathbf{1 0 6}$ \\
\hline vzorek & $\mathrm{AU} 1$ & AU5 & AU5 & AU5 & AU5 \\
\hline $\mathrm{SiO}_{2}$ & 39,44 & 38,39 & 40,59 & 44,38 & 39,06 \\
\hline $\mathrm{TiO}_{2}$ & 0,05 & 0,04 & 0,03 & 0,02 & 0,26 \\
\hline $\mathrm{Al}_{2} \mathrm{O}_{3}$ & 28,98 & 28,73 & 29,69 & 25,47 & 25,86 \\
\hline $\mathrm{Fe}_{2} \mathrm{O}_{3}$ & 9,03 & 9,56 & 7,20 & 10,22 & 12,77 \\
\hline $\mathrm{MnO}$ & 0,12 & 0,16 & 0,10 & 0,13 & 0,04 \\
\hline $\mathrm{MgO}$ & 0,00 & 0,88 & 1,45 & 0,01 & 0,13 \\
\hline $\mathrm{CaO}$ & 24,10 & 22,74 & 22,40 & 22,33 & 24,14 \\
\hline celkem & 101,71 & 100,50 & 101,46 & 102,55 & 102,25 \\
\hline $\mathrm{Si}$ & 2,965 & 2,922 & 3,019 & 3,275 & 2,964 \\
\hline $\mathrm{Ti}$ & 0,003 & 0,002 & 0,002 & 0,001 & 0,015 \\
\hline $\mathrm{Al}$ & 2,567 & 2,577 & 2,602 & 2,215 & 2,313 \\
\hline $\mathrm{Fe}^{3+}$ & 0,511 & 0,548 & 0,403 & 0,568 & 0,729 \\
\hline $\mathrm{Mn}$ & 0,007 & 0,010 & 0,007 & 0,008 & 0,003 \\
\hline $\mathrm{Mg}$ & 0,000 & 0,100 & 0,161 & 0,001 & 0,015 \\
\hline $\mathrm{Ca}$ & 1,941 & 1,854 & 1,785 & 1,765 & 1,962 \\
\hline celkem & 7,993 & 8,013 & 7,977 & 7,833 & 8,000 \\
\hline $\mathrm{Fe}{ }^{3+} /\left(\mathrm{Fe}^{3+}+\mathrm{Al}\right)$ & 0,17 & 0,18 & 0,13 & 0,20 & 0,24 \\
\hline & & & & & \\
\hline
\end{tabular}

Ostatní výsledky jsou k dispozici v elektronické př́lloze. Analýzy zlata nebyly provedeny, protože došlo při př́pravě vzorku (broušení) ke ztrátě klastů zlata v obou vzorcích.

\section{Charakter sedimentů}

Písčitý sediment z lokality AU1 (obr. 2a) obsahuje často větší ostrohranné až slabě zaoblené klasty štěrkové frakce (až $20 \mathrm{~cm}$, obr. 2b), které svým petrografickým složením odpovídají bazickým vulkanickým a plutonickým horninám. Tyto horniny jsou z petrografického hlediska velmi podobné vyvřelým horninám $\mathrm{v}$ nejbližším okolí lokality. Místy jsou však také přítomny dobře opracované křemenné valounky o velikosti až $3 \mathrm{~cm}$. Špatně vytříděná písčitá matrix obsahuje vždy nad $10 \mathrm{hm}$. \% prachovité př́měsi (obr. 2b). Vzorek o hmotnosti $22 \mathrm{~kg}$ byl odebrán prímo na skalním podloží v hloubce $1,2 \mathrm{~m}$.

Sedimenty na lokalitě AU5 (obr. 2d) obsahují špatně vytříděné písčité a štěrkovité polohy (mocnost do $25 \mathrm{~cm}$ ), které se místy střídají s polohami prachovité hlíny (obr. 2e). Bohužel se na celém ložisku nepodařilo nalézt profil, který by nebyl postižen antropogenní činností, proto je vhorní části profilu velké množství velkých horninových úlomků, které pocházejí ze dna sondy (obr. 2e). Dominantní jsou písky a štěrky s vysokým obsahem prachovité komponenty nebo písčité štěrky. Mezi ostrohrannými klasty štěrku dominují ultrabazické a bazické vyvřelé horniny. Méně jsou zastoupeny slabě zaoblené vápence. Vzorek o hmotnosti $15 \mathrm{~kg}$ byl odebrán prrímo ze stěny sondy v hloubce $1,5 \mathrm{~m}$ (z písčité polohy těsně nad štěrky).

\section{Asociace těžkých minerálů a morfologie zlata}

Obsahy zlata jsou v obou vzorcích malé a nepřesahují 0,3\%. Oba studované vzorky se výrazně liší v zastoupení průsvitných těžkých minerálů (obr. 2c, f) a obsahují významné zastoupení opakních minerálů (tab. 1) jako je magnetit (31 a $32 \%)$, chromit (1 a $27 \%)$, pyrit (3 a $13 \%)$ a ilmenit (kolem $1 \%)$.

Vzorek AU1 obsahuje zaoblené klasty zlata (obr. 3a), které nesou známky delšího fluviálního transportu. Ve vzorku bylo nalezeno 6 klastů zlata $\mathrm{z}$ nichž největší měl délku zhruba $1 \mathrm{~mm}$ a nejmenší $0,5 \mathrm{~mm}$. Většina zrn zlata je slabě až středně zaoblená, elipsoidového až doutníkovitého tvaru (částečně nebo úplně srolované) a na povrchu poškrábaná. Zrna magnetitu a ilmenitu nesou známky pouze slabého opracování a bývají většinou omezena krystalovými plochami. Průsvitné těžké minerály (tab. 1) jsou reprezentovány hlavně polozaoblenými až zaoblenými klasty amfibolu (obr. 3b, 19\%) a ostrohrannými až zaoblenými zirkony 

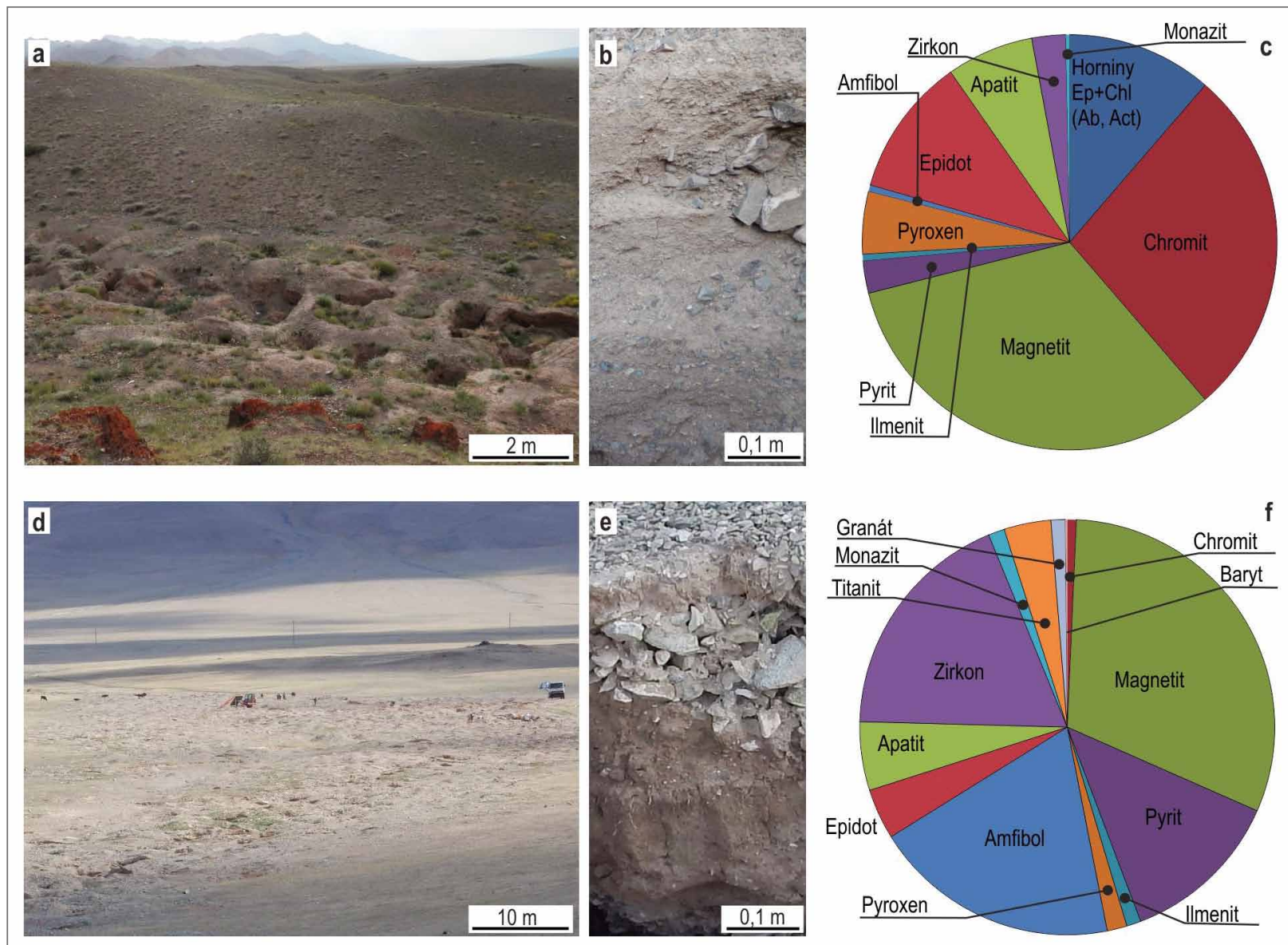

Obr. 2: Pozůstatky po těžbě na místech odběru vzorků $(a, d)$, sedimentární profil $(b, e)$ a složení těžké frakce $(c, f)$ z písčitých sedimentů na lokalitách Khaliun (c, f), AU1 (a-c) a Altaj, AU5 (d-f).

Fig. 2: Mining activities at the sampling sites $(a, d)$, sediment profile (b, e) and heavy mineral composition of the sandy sediments from the localities of Khaliun (c, f), AU1 (a-c) and Altai, AU5 (d-f).

(obr. 3b-c, $18 \%$ ). Relativně hojné jsou také polozaoblené až zaoblené klasty epidotu, apatitu a titanitu. V malém množství jsou př́tomny polozaoblené pyroxeny, granáty a destičkovité krystaly barytu (obr. 3c).

Vzorek AU5 obsahuje plíšky zlata, které jsou minimálně postiženy transportem. Ve vzorku bylo nalezeno 7 drobných klastů zlata, $\mathrm{z}$ nichž největší měl délku $0,5 \mathrm{~mm}$ a nejmenší $0,2 \mathrm{~mm}$. Nepravidelné, někdy oválné plíšky, mají na povrchu výčnělky a zbytky krystalových tvarů (obr. 3d). Některé plíšky jsou na okrajích ohnuté (částečně srolované okraje), avšak nebyla nalezena žádná zcela srolovaná zrna. Některé plíšky jsou uzavřeny do jemně zrnitého dolomitu a vzácně také do mléčně bílého křemene. $\mathrm{V}$ asociaci těžkých minerálů naprosto dominují minerály bez známek opracování fluviálním transportem. Zejména chromity (obr. 3e) a magnetity si zachovávají svůj původní krystalový tvar. Průsvitné těžké minerály (tab. 1) jsou reprezentovány hlavně krystaly epidotů a pyroxenů, které bývají pouze někdy slabě zakulacené (obr. 3d). Zirkony, apatity a rutily jsou poměrně vzácné a bývají slabě zakulacené. Hojné jsou drobné agregáty zrn, mezi nimiž obvykle dominuje epidot. Obvykle se jedná o drobné ostrohranné až polozaoblené úlomky zelených břidlic, které se skládají z minerálů epidotové skupiny, chloritu, amfibolu a někdy také albitu.

\section{Diskuze}

\section{Variabilita $v$ chemickém složení těžkých minerálů a jejich původ}

Ve vzorku z lokality poblíž města Khaliun (AU1) jsou výrazně zastoupena polozaoblená sloupcovitá zrna amfibolu, který má homogenní složení odpovídající podle klasifikace magnesiohornblendu až pargasitu (obr. 4a, podle klasifikace Hawthorna et al. 2012). Chemické složení těchto amfibolů dobře souhlasí se složením amfibolů v horninách vulkanického oblouku Ikh-Mongol (Janoušek et al. 2018) a liší se od publikovaných dat z bazických hornin khantaishirského ofiolitového komplexu (Gianola et al. 2019). Vzácně se vyskytují slabě opracovaná štěpná zrna diopsidu $(\mathrm{Fe} / \mathrm{Fe}+\mathrm{Mg}=0,13$; tab. 2). Chemické složení tohoto pyroxenu (obr. 4b) je podobné chemickému složení klinopyroxenů $\mathrm{z}$ hornin vulkanického oblouku Ikh-Mongol (Janoušek et al. 2018) a khantaischirského ofiolitového komplexu (Matsumoto, Tomurtogoo 2003; Gianola et al. 2019). Ve vzorku AU1 byly analyzovány ilmenity, které obsahují velmi nízké obsahy Mn (obr. 4c, obsahy pyrophanitové komponenty se pohybují v rozmezí 4-20 hm. \%). Takové složení je typické pro bazické horniny (Nayak, Mohapatra 1998) nebo metapelity (Abu El-Enen et al. 2003). Stejné složení mají také ilmenity z magmatických hornin vulkanický oblouk Ikh-Mongol 

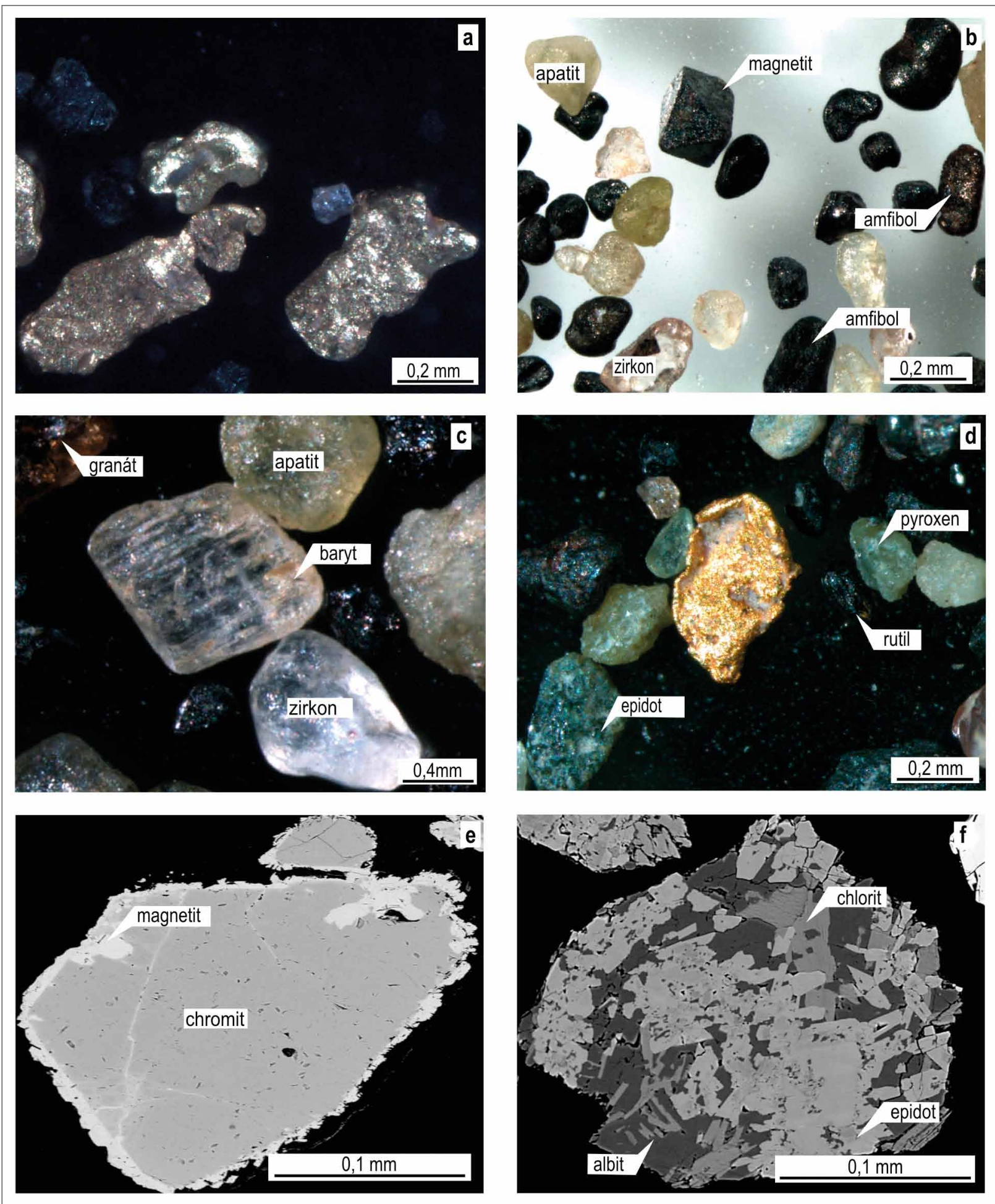

Obr. 3: Mikrofotografie vybraných těžkých minerálů ze vzorků AU 1 (a-c) a AU5 (d-f): (a) zakulacené plíšky zlata, (b) typické těžké minerály (amfibol, zirkon, apatit, magnetit) s variabilním stupněm opracování, (c) krystal barytu mezi zrny apatitu, granátu a zirkonu, (d) drobný málo opracovaný plíšek zlata místy s povlaky dolomitu, (e) krystal chromitu lemovaný mladším magnetitem (BSE snímek), (f) slabě zakulacený úlomek zelené břidlice složený z albitu, chloritu a minerálů epidotové skupiny (BSE snímek). Fig. 3: Micrographs of selected heavy minerals from samples AU $1(\mathrm{a}-\mathrm{c})$ and AU5 (d-f): (a) subspherical rounded shape of the gold particles, (b) typical heavy minerals (amphibole, zircon, apatite, magnetite) with a variable degree of rounding of clasts, (c) barite crystal between apatite, garnet and zircon grains; (d) slightly rounded three-dimensional gold particle with dolomite coatings, (e) euhedral chromite crystal rimmed with magnetite (BSE-image), (f) slightly rounded clast greenschist consists of albite, chlorite, and minerals epidote group (BSE-image).

(obr. 4c, nepublikovaná data autora DB). Chemické složení minerálů epidotové skupiny (tab. 3) leží mezi epidotem a klinozoisitem $\left(\mathrm{Fe}^{3+} /\left(\mathrm{Fe}^{3+}+\mathrm{Al}\right)=0,17\right)$. Poměrně hojné jsou v tomto vzorků polozaoblené klasty titanitů, které se makroskopicky podobají titanitům v granitoidů vulkanického oblouku Ikh-Mongol (Janoušek et al. 2018). Titanity 


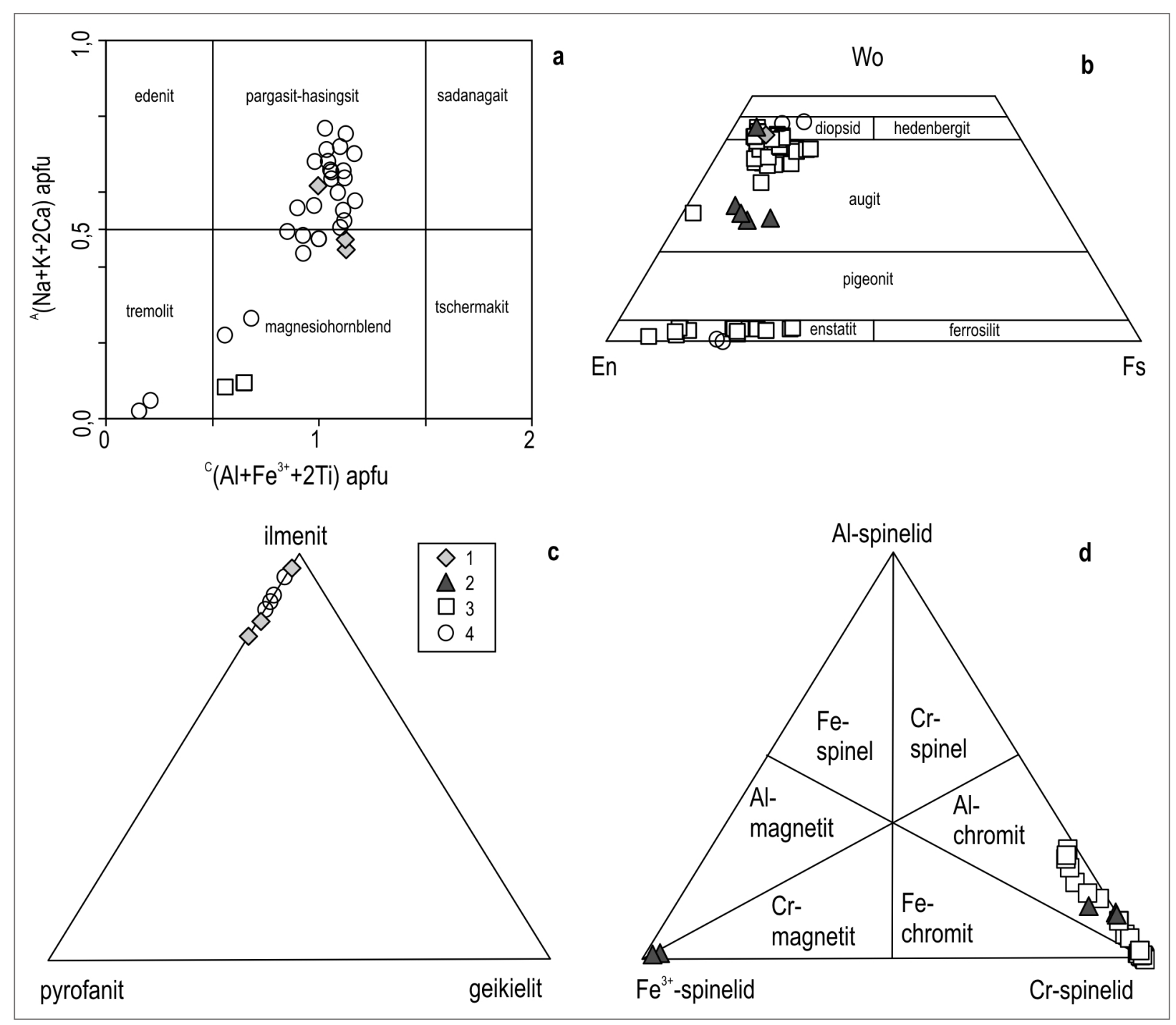

Obr. 4: Klasifikační diagramy pro vybrané těžké minerály ze vzorků AU1 a AU5: (a) ${ }^{\mathrm{C}}\left(\mathrm{Al}+\mathrm{Fe}^{3+}+2 \mathrm{Ti}\right)$ vs. ${ }^{\mathrm{A}}(\mathrm{Na}+\mathrm{K}+2 \mathrm{Ca})$ binární klasifikační diagram pro amfiboly (Hawthorn et al. 2012), (b) En-Wo-Fs ternární klasifikační diagram pro pyroxeny (Morimoto et al. 1988), (c) pyrofanit - ilmenit - geikielit ternární klasifikační diagram pro ilmenity, (d) $\mathrm{Fe}^{3+}$-spinelid-Al-spinelid-Fe-spinelid ternární klasifikační diagram pro spinelidy (podle Stevense 1944), $[1$ = AU1, 2 = AU5, 3 = chemické složení minerálů z hornin vulkanického oblouku Ikh-Mongol, převzato z práce Janoušek et al. (2018) a z nepublikovaných dat autora, $4=$ chemické složení minerálů typických pro khantaishirský ofiolitový komplex je převzato z prací (Matsumoto, Tomurtogoo 2003; Gianola et al. 2019)]. Fig. 4: Classification diagrams for selected heavy minerals from the samples AU1 and AU5 (a) ${ }^{\mathrm{C}}\left(\mathrm{Al}+\mathrm{Fe}^{3+}+2 \mathrm{Ti}\right) \mathrm{vs} .{ }^{\mathrm{A}}(\mathrm{Na}+\mathrm{K}+2 \mathrm{Ca})$ binary classification chart for amphiboles (Hawthorn et al. 2012), (b) En-Wo-Fs ternary classification diagram for pyroxenes (Morimoto et al. 1988), (c) pyropanite-ilmenite-geikielite ternary classification diagram for ilmenites, (d) $\mathrm{Fe}^{3+}$-spinelide-Al-spinelide-Fe-spinelide ternary classification diagram for spinelides (after Stevens, 1944), $[1=$ AU1, 2 = AU5, 3 = chemical composition of minerals from rocks of volcanic arch Ikh-Mongol (circle) taken from Janoušek et al. (2018) and from the unpublished data of the author, $4=$ chemical composition of minerals typical of the Khantaishir ophiolite complex (square) is taken from published papers (Matsumoto, Tomurtogoo 2003; Gianola et al. 2019)].

jsou navíc časté v celé řadě metamorfovaných hornin. Studované klasty titanitu mají nízké obsahy Fe (celkové FeO se pohybuje v rozmezí 1,6-1,7 hm. \%) a Al (celkové $\mathrm{Al}_{2} \mathrm{O}_{3}$ se pohybuje v rozmezí 1,4-1,5 hm. \%). Oválná zrna monazitů mají homogenní složení s obsahem $\mathrm{ThO}_{2} \mathrm{v}$ rozmezí 5,8 až $12,9 \mathrm{hm}$. \% a s obsahem $\mathrm{SiO}_{2}$ do $2,7 \mathrm{hm}$. \%. Monazity o tomto složení jsou běžné v granitických horninách a metapelitech (Foerster 1998). Vzácně se vyskytují drobné krystalky barytu, které pravděpodobně indikují přítomnost hydrotermálních žil ve zdrojové oblasti. Slabě opracovaná zrna zirkonů mají nízké obsahy $\mathrm{HfO}_{2}\left(1,0-1,5 \mathrm{hm}\right.$. \%) a velmi nízké obsahu U a Th $\left(\mathrm{ThO}_{2}\right.$ maximálně $0,08 \mathrm{hm}$. \%). Zirkony o tomto složení mohou pocházet z kyselých nebo z bazických hornin (Breiter et al. 2006; Belousova et al. 2002). Zirkon se běžně vyskytuje v komplexu hornin vulkanického oblouku Ikh-Mongol (Janoušek et al. 2018).

Ve vzorku AU5 byla analyzována krystalově omezená zrna chromitu (obr. 4d) a magnetitu. Tyto minerály můžeme texturně rozdělit do několika skupin: (a) homogenní chromity, (b) jádro tvořené chromitem je lemováno ferrichromitem (chromit s obsahem $\mathrm{Fe}^{3+} \mathrm{v}$ rozmezí 0,51,0 apfu) nebo magnetitem, (c) magnetit s odmíšeninami ilmenitu nebo rutilu, (d) homogenní magnetit. Chemické 
složení chromitu poměrně dobře odpovídá chemickému složení spinelidů, které byly popsány $\mathrm{z}$ khantaishirského ofiolitového komplexu (Matsumoto, Tomurtogoo 2003; Gianola et al. 2019). Magnetity mohou pocházet z ultrabazických nebo $\mathrm{z}$ bazických hornin. Vzácně se zde také objevují polozaoblená až ostrohranná zrna ilmenitu, která však nebyla analyzována. Byly zjištěny blíže neurčené Fe-Ni sulfidy a hojný sekundárně alterovaný pyrit (limonitizace). Často se vyskytují polozaoblená štěpná zrna klinopyroxenu $(\mathrm{Fe} / \mathrm{Fe}+\mathrm{Mg}=0,08-0,23, \mathrm{Ca}=0,94-0,49$ apfu). Chemické složení jednoho analyzovaného zrna diopsidu odpovídá chemickému složení klinopyroxenů z khantaishirského ofiolitového komplexu (Matsumoto, Tomurtogoo 2003; Gianola et al. 2019). Dominantní klinopyroxeny (tab. 2) odpovídají augitu, který patrně pochází z vulkanických hornin, vyskytujících se jako ostrohranné klasty ve štěrkovitých polohách na popisované lokalitě. Běžná jsou polozaoblená až poloostrohranná zrna minerálů epidotové skupiny $\left(\mathrm{Fe}^{3+} /\left(\mathrm{Fe}^{3+}+\mathrm{Al}\right)=0,13-0,24\right.$; tab. 3).

\section{Zdrojové oblasti studovaných sedimentů}

Na základě zjištěných asociací těžkých minerálů můžeme interpretovat možné zdrojové oblasti studovaných sedimentů. Lokalita AU1 je situována na drobném občasném toku, jehož snosová oblast nepřesahuje $1 \mathrm{~km}^{2}$. Ve zmíněné oblasti dominantně vystupují bazické vulkanické a ultrabazické plutonické horniny. Tato skutečnost neodpovídá zjištěnému spektru těžkých minerálů. Popisovaný tok však také drénuje oblast s výskytem starších fluviálních sedimentů. Řkka, která usadila zmíněné sedimenty, se nachází ve vedlejším údolí a má poměrně rozsáhlé povodí situované jv. od popisované lokality. V tomto povodí vystupují různé typy neoproterozoických až kambrických metasedimentů (svory, fylity, metapískovce), kambrické sedimenty a vulkanity, plutonické horniny vulkanického oblouku Ikh-Mongol a permské vulkanity (obr. 1). Horniny vystupující v povodí řeky mohly poskytnout celou asociaci těžkých minerálů ve studovaném vzorku. Tento názor je také v dobrém souladu s relativně velkým stupněm fluviálního opracování zlata (obr. 4a) a variabilním stupněm opracování ostatních těžkých minerálů. Baryt stejně tak jako vysoké zastoupení pyritu, naznačuje př́tomnost hydrotermálních žil, $\mathrm{z}$ nichž by mohlo pocházet také zlato. Nicméně prrímé důkazy, které by umožnily identifikovat původ zlata, však chybí.

$\mathrm{V}$ případě lokality AU5 je snosová oblast podle satelitního snímku situována hlavně jv. od studované lokality (celkový plocha kolem $6 \mathrm{~km}^{2}$ ). V této oblasti dominují ultrabazické horniny khantaishirského ofiolitového komplexu (Gibsher et al. 2001; obr. 1). Podle terénního průzkumu se zde hojně vyskytují neoproterozoické vulkanity a vápence. Spektrum těžkých minerálů tedy odpovídá geologické situaci snosové oblasti, která je situována $4-5 \mathrm{~km}$ j. až jv. od studované lokality. Charakter sedimentů (petrografické složení a opracování klastů) naznačuje krátký transport přívalovými dešti. Morfologie zlata (obr. 4d) jednoznačně potvrdila krátký transport a vazbu zlata s dolomitem a křemenem, což jsou typické minerály, které provázejí zlato $\mathrm{z}$ hydrotermálně alterovaných ultrabazických hornin. Typickým nositelem zlata bývá listvenit, což je hornina složená hlavně z karbonátů a sekundárních fylosilikátů jako je mastek a minerálů serpentinové skupiny. Listvenit vzniká metasomatickou přeměnou ultrabazických hornin (např. Hansen et al. 2005) a běžně obsahuje karbonátové a křemenné žilky (Matter, Kelemen 2009).

\section{Závěry}

Dvě studované lokality rozsypového zlata prostorově svázané s khantaishirským ofiolitovým komplexem poskytly spektra těžkých minerálů navzájem odlišného složení. Identifikace zdrojových hornin pro tyto těžké minerály přispěla $\mathrm{k}$ určení původu zlata.

Lokalita situovaná jv. od městečka Khaliun (vzorky AU1) obsahuje sedimenty, které se vyskytují v blízkém okolí (magnetit, pyroxen). Avšak těžké minerály jako granát, ilmenit, titanit patrně pocházejí ze vzdálenějších zdrojů. Předpokládáme, že občasné toky v této oblasti erodovaly starší říční sedimenty uložené řekou, která dnes teče ve vedlejším údolí. To je v poměrně v dobrém souladu se zjištěným spektrem těžkých minerálů. Vedle sebe zde koexistují slabě až silně opracované těžké minerály typické pro plutonické horniny vulkanického oblouku (amfibol, ilmenit, titanit) a intenzivně metamorfované vulkanosedimentární komplexy a kyselé vyvřeliny (granát, zirkon, monazit). Klasty zlata nesou známky opracování ve fluviálním prostředí.

Lokalita u města Altaj (AU5) je situována na sedimentech, které vznikly činností občasných toků drénujících horský hřbet, budovaný převážně ofiolitovým komplexem (hlavně ultrabazickými horninami a bazickými vulkanity). Nízké zaoblení klastů, stejně tak jako dominance drobných úlomků bazických a ultrabazických hornin z blízkého okolí, naznačují krátký transport sedimentárního materiálu (na základě geologické mapy a satelitních snímků odhadujeme plochu snosové oblasti na $6 \mathrm{~km}^{2}$ ). Ve spektru těžkých minerálů dominují špatně opracovaná zrna, která pravděpodobně pocházejí z bazických a ultrabazických hornin khantaishirského ofiolitového komplexu (magnetity, chromity, pyroxeny, epidoty). Také zlato nenese známky opracování nebo je málo opracované (ohnuté okraje). Mezi těžkými minerály se poměrně často vyskytují drobné úlomky bazických slabě metamorfovaných hornin bohatých epidotem.

Studované vzorky jsou dobrým prŕkladem sedimentů transportovaných občasnými toky v aridních oblastech. Většina klastického materiálu transportovaného občasnými toky je málo opracovaná. Klasty hornin pocházejí ze vzdálenosti, která nepřesahuje deset kilometrů. Tomu odpovídá i stupeň opracování a variabilita těžkých minerálů. V aridních oblastech existují také stálé toky, které transportují dobře opracované klasty na vzdálenosti mnoha desítek kilometrů. Tyto dobře vytříděné klastické sedimenty pak mohou být později redeponovány lokálními občasnými toky. 


\section{Poděkování}

Předložená práce vznikla za finanční podpory projektů České geologické služby číslo 321180 („Základní geologické mapování, které je součástí DKRVO/ČGS (2018-2022)“). Autoři děkují T. Sidorinové a J. Večeřovi za cenné připomínky k manuskriptu.

\section{Literatura}

Abu El-Enen, M., Okrusch, M., Will, T. (2003). Metapelitic assemblages in the Umm Zariq schists, central western Kid Belt, Sinai Peninsula, Egypt. - Neues Jahrbuch für Mineralogie Abhandlungen 178, 277-306. http://doi:10.1127/0077-7757/2003/01780277

Belousova, E., Griffin, W., O’Reilly, S., Fisher, N. (2002). Igneous zircon - Trace element composition as an indicator of source rock type. - Contributions Mineralogy and Petrology 143, 602-622. http://doi:10.1007/s00410-002-0364-7

Breiter, K., Förster, H. J., Škoda, R. (2006). Extreme P-, Bi-, Nb-, Sc-, U- and F-rich zircon from fractionated perphosphorous granites. The peraluminous Podlesí granite system, Czech Republic. - Lithos 88, 15-34. http://doi:10.1016/j.lithos.2005.08.011

Droop, G., T., R. (1987). A general equation for estimating $\mathrm{Fe}^{3+}$ in ferromagnesian silicates and oxides from microprobe analysis, using stoichiometric criteria. - Mineralogical Magazine 51, 431-437.

Foerster, H-J. (1998). The chemical composition of REE-Y-Th-U-rich accessory minerals in peraluminous granites of the Erzgebirge-Fichtelgebirge region, Germany; Part I, The monazite-(Ce) - brabantite solid solution series. - American Mineralogist 83, 3-4, 259-272. http://doi:10.2138/am-1998-3-409

Gianola, O., Schmidt, M. W., Jagoutz, O., Rickli, J., Bruguier, O., Sambuu, O. (2019). The Crust-Mantle Transition of the Khantaishir Arc Ophiolite (Western Mongolia). - Journal of Petrology 60, 4, 673-700 http://doi:10.1093/petrology/egz009

Gibsher, A. S., Khain, E. V., Kotov, A. B., Salnikova, E.V., Kozakov, I. K., Kovach, V. P., Yakovleva, S. Z., Fedorenko, A. M. (2001). Late Vendian age of the Han - Taishiri ophiolite complex in western Mongolia. - Russian Geology and Geophysics 42, 1110-1117.

Hansen, L. D., Dipple, G. M., Gordon, T. M., Kellett, D. A. (2005). Carbonated serpentinite (listwanite) at Alin, British Columbia a geological analogue to carbon dioxide sequestration. - Canadian Mineralogist 43, 225-239.

Hanžl, P., Guy, A., Battushig, A., Lexa, O., Schulmann, K., Kunceová, E., Hrdličková, K., Buriánek, D., Krejčí, Z., Jiang, Y., Otgonbator, D. (2019). Geology of the Gobi and Mongol Altai junction enhanced by gravity analysis - a key for understanding of the Mongolian Altaides. - Journal of Maps 16, 2, 98-107. ISSN 1744-5647. http://doi 10.1080/17445647.2019.1700835

Hawthorne, F. C., Oberti, R., Harlow, G. E., Maresch, W. V., Martin, R. F., Schumacher, J. C. m., Welch, M. D. (2012). IMAreport, nomenclatureoftheamphibolesupergroup. - American Mineralogist 97, 2031-2048.

Janoušek, V., Jiang, Y., Buriánek, D., Schulmann, K., Hanžl, P., Soejono, I., Kröner, A., Altanbaatar, B., Erban, V., Lexa, O., Ganchuluun, T., Košler, J. (2018). Cambrian - Ordovician magmatism of the Ikh-Mongol Arc System exemplified by the Khantaishir Magmatic Complex (Lake Zone, south-central Mongolia). - Gondwana Research 54, 122-149 https://doi. org/10.1016/j.gr.2017.10.003

Matsumoto, I., Tomurtogoo, O. (2003). Petrological characteristics of the Hantaishir ophiolite complex, Altai Region, Mongolia. coexistence of podiform chromitite and boninites. - Gondwana Research 6, 161-169.

Matter, J. M., Kelemen, P. B. (2009). Permanent storage of carbon dioxide in geological reservoirs by mineral carbonation. - Nature Geoscience 2, 12, 837-841. doi:10.1038/ngeo683

Morimoto, N., Fabries, J., Ferguson, A. K., Ginzburg, I. V., Ross, M., Seifert, F. A., Zussman, J., Aoki, K. (1988). Nomenclature of pyroxenes. - Mineralogical Magazine 52, 535-550.

Morton, A.C., Hallsworth, C. R. (1994). Identifying provenance-specific features of detrital heavy mineral assemblages in sandstones. - Sedimentary Geology, 90, 241-256.

Nayak, B. R., Mohapatra, B. K. (1998). Two morphologies of pyrophanite in Mn-rich assemblages, Gangpur Group, India. - Mineralogical Magazine 62, 847-856.

Rost, R. (1956). Těžké minerály - příručka k určování těžkých minerálů ve výplavech. - Nakladatelství Československé akademie věd. pp238, Praha.

Stevens, R. E. (1944). Composition of some chromites of the Western Hemisphere. - American Mineralogist, 29, 1-34.

Zabotkin, L. B. (1988). Geological and mineral resources maps of L-47-XXII, XXIII, XXIV, XXVIII, XXIX, XXX, XXXIV, XXXV, and XXXVI quadrants. - Ulaanbaatar, Mongolia, Geologic Information Center, Open - file Report 4276, scale $1: 200,000$ (in Russian).

Zonenshain, L. P., Kuzmin, M. I. (1978). The Khan-Taishir ophiolitic complex of western Mongolia, its petrology, origin and comparison with other ophiolitic complexes. - Contributions Mineralogy and Petrology 67, 95-109. 
Elektronická př́loha č. 1 obsahuje chemické složení vybraných minerálů ze vzorků AU1 a AU5 (ilmenit, spinelidy, monazit, amfibol) Electronic supplementary materials No. 1 contains a chemical composition of selected minerals from samples AU1 and AU5 (ilmenite, spinelides, monazite, amphibole)

Tab. I: Chemické složení ilmenitu ve vzorku AU1 Tab. I: Chemical composition of ilmenite from sample AU1

\begin{tabular}{|l|r|r|r|}
\hline analýza & $\mathbf{1 0 8}$ & $\mathbf{1 1 6}$ & $\mathbf{1 2 0}$ \\
\hline vzorek & $\mathrm{AU} 1$ & $\mathrm{AU} 1$ & AU1 \\
\hline $\mathrm{SiO}_{2}$ & 0,00 & 0,00 & 0,08 \\
\hline $\mathrm{TiO}_{2}$ & 50,23 & 50,25 & 50,04 \\
\hline $\mathrm{Al}_{2} \mathrm{O}_{3}$ & 0,01 & 0,00 & 0,03 \\
\hline $\mathrm{Cr}_{2} \mathrm{O}_{3}$ & 0,01 & 0,00 & 0,00 \\
\hline $\mathrm{V}_{2} \mathrm{O}_{3}$ & 0,00 & 0,00 & 0,22 \\
\hline $\mathrm{Fe}_{2} \mathrm{O}_{3}$ & 6,58 & 6,34 & 5,62 \\
\hline $\mathrm{FeO}$ & 37,02 & 35,25 & 42,78 \\
\hline $\mathrm{MnO}$ & 7,62 & 9,53 & 2,02 \\
\hline $\mathrm{MgO}$ & 0,22 & 0,04 & 0,15 \\
\hline $\mathrm{CaO}$ & 0,01 & 0,02 & 0,00 \\
\hline $\mathrm{ZnO}$ & 0,05 & 0,24 & 0,03 \\
\hline celkem & 101,75 & 101,67 & 100,96 \\
\hline $\mathrm{Si}$ & 0,000 & 0,000 & 0,004 \\
\hline $\mathrm{Ti}$ & 1,877 & 1,881 & 1,885 \\
\hline $\mathrm{Al}$ & 0,000 & 0,000 & 0,002 \\
\hline $\mathrm{Cr}$ & 0,000 & 0,000 & 0,000 \\
\hline $\mathrm{V}$ & 0,000 & 0,000 & 0,009 \\
\hline $\mathrm{Fe}{ }^{3+}$ & 0,246 & 0,237 & 0,212 \\
\hline $\mathrm{Fe}{ }^{2+}$ & 1,538 & 1,467 & 1,791 \\
\hline $\mathrm{Mn}$ & 0,321 & 0,402 & 0,086 \\
\hline $\mathrm{Mg}$ & 0,016 & 0,003 & 0,011 \\
\hline $\mathrm{Ca}$ & 0,001 & 0,001 & 0,000 \\
\hline $\mathrm{Zn}$ & 0,002 & 0,009 & 0,001 \\
\hline celkem & 4,000 & 4,000 & 4,000 \\
\hline $\left.\mathrm{Ilm}(\mathrm{FeTiO})_{3}\right)$ & 0,77 & 0,74 & 0,89 \\
\hline $\mathrm{Prph}\left(\mathrm{MnTiO}_{3}\right)$ & 0,16 & 0,20 & 0,04 \\
\hline $\mathrm{Geik}\left(\mathrm{MgTiO}_{3}\right)$ & 0,01 & 0,00 & 0,01 \\
\hline $\mathrm{Hem}\left(\mathrm{Fe}_{2} \mathrm{O}_{3}\right)$ & 0,06 & 0,06 & 0,06 \\
\hline & & & \\
\hline
\end{tabular}

Tab. III: Chemické složení monazitu ve vzorku AU

Tab. III: Chemical composition of monazite from sample AU1

\begin{tabular}{|c|c|c|}
\hline analýza & 118 & 119 \\
\hline vzorek & AU1 & AU1 \\
\hline $\mathrm{P}_{2} \mathrm{O}_{5}$ & 30,23 & 26,30 \\
\hline $\mathrm{SiO}_{2}$ & 0,29 & 2,66 \\
\hline $\mathrm{CaO}$ & 1,41 & 0,51 \\
\hline $\mathrm{La}_{2} \mathrm{O}_{3}$ & 15,73 & 16,57 \\
\hline $\mathrm{Ce}_{2} \mathrm{O}_{3}$ & 29,46 & 28,89 \\
\hline $\mathrm{Pr}_{2} \mathrm{O}_{3}$ & 2,92 & 2,70 \\
\hline $\mathrm{Nd}_{2} \mathrm{O}_{3}$ & 9,49 & 8,40 \\
\hline $\mathrm{Sm}_{2} \mathrm{O}_{3}$ & 1,91 & 0,59 \\
\hline $\mathrm{Y}_{2} \mathrm{O}_{3}$ & 0,82 & 0,20 \\
\hline $\mathrm{ThO}_{2}$ & 5,83 & 12,93 \\
\hline $\mathrm{UO}_{2}$ & 0,42 & 0,21 \\
\hline $\mathrm{Er}_{2} \mathrm{O}_{3}$ & 0,05 & 0,00 \\
\hline $\mathrm{Gd}_{2} \mathrm{O}_{3}$ & 0,64 & 0,23 \\
\hline $\mathrm{Dy}_{2} \mathrm{O}_{3}$ & 0,43 & 0,13 \\
\hline $\mathrm{Yb}_{2} \mathrm{O}_{3}$ & 0,02 & 0,00 \\
\hline $\mathrm{PbO}$ & 0,10 & 0,21 \\
\hline celkem & 99,75 & 100,53 \\
\hline $\mathrm{O}$ & 4,000 & 4,000 \\
\hline $\mathrm{P}$ & 0,997 & 0,898 \\
\hline $\mathrm{Si}$ & 0,011 & 0,107 \\
\hline $\mathrm{Ca}$ & 0,058 & 0,022 \\
\hline $\mathrm{La}$ & 0,226 & 0,246 \\
\hline $\mathrm{Ce}$ & 0,420 & 0,426 \\
\hline $\mathrm{Pr}$ & 0,041 & 0,040 \\
\hline $\mathrm{Nd}$ & 0,132 & 0,121 \\
\hline $\mathrm{Sm}$ & 0,026 & 0,008 \\
\hline $\mathrm{Y}$ & 0,017 & 0,004 \\
\hline Th & 0,052 & 0,119 \\
\hline $\mathrm{U}$ & 0,004 & 0,002 \\
\hline $\mathrm{Er}$ & 0,001 & 0,000 \\
\hline Gd & 0,008 & 0,003 \\
\hline Dy & 0,005 & 0,002 \\
\hline $\mathrm{Yb}$ & 0,000 & 0,000 \\
\hline $\mathrm{Fe}$ & 0,000 & 0,000 \\
\hline $\mathrm{Mn}$ & 0,000 & 0,000 \\
\hline $\mathrm{Mg}$ & 0,000 & 0,000 \\
\hline $\mathrm{Al}$ & 0,000 & 0,000 \\
\hline $\mathrm{Pb}$ & 0,001 & 0,002 \\
\hline celk. kat. & 2,000 & 2,000 \\
\hline $2 \mathrm{ThSiO}_{4}$ & 1 & 11 \\
\hline $2 \mathrm{CePO}_{4}$ & 88 & 85 \\
\hline $\mathrm{CaThPO}_{4}$ & 10 & 4 \\
\hline $\mathrm{REE}+\mathrm{Y}+\mathrm{P}$ & 1,87 & 1,75 \\
\hline $\mathrm{Th}+\mathrm{U}+\mathrm{Si}$ & 0,07 & 0,23 \\
\hline
\end{tabular}

Tab. II: Chemické složení spinelidů ve vzorku AU5

Tab. II: Chemical composition of spinelides from sample AUs

\begin{tabular}{|l|r|r|r|r|r|}
\hline analýza & $\mathbf{9 0}$ & $\mathbf{9 1}$ & $\mathbf{9 2}$ & $\mathbf{9 4}$ & $\mathbf{9 5}$ \\
\hline vzorek & $\mathrm{AU} 5$ & $\mathrm{AU} 5$ & $\mathrm{AU} 5$ & $\mathrm{AU} 5$ & $\mathrm{AU} 5$ \\
\hline $\mathrm{SiO}_{2}$ & 0,07 & 0,06 & 0,05 & 0,03 & 0,03 \\
\hline $\mathrm{TiO}_{2}$ & 0,15 & 0,01 & 0,03 & 0,05 & 0,14 \\
\hline $\mathrm{Al}_{2} \mathrm{O}_{3}$ & 5,68 & 0,00 & 5,64 & 0,00 & 6,51 \\
\hline $\mathrm{Cr}_{2} \mathrm{O}_{3}$ & 65,24 & 1,26 & 64,13 & 0,33 & 60,55 \\
\hline $\mathrm{V}_{2} \mathrm{O}_{3}$ & 0,29 & 0,03 & 0,33 & 0,03 & 0,16 \\
\hline $\mathrm{NiO}$ & 0,00 & 0,81 & 0,04 & 0,03 & 0,07 \\
\hline $\mathrm{Fe}_{2} \mathrm{O}_{3}$ & 0,00 & 68,95 & 0,08 & 67,39 & 3,65 \\
\hline $\mathrm{FeO}$ & 19,96 & 27,86 & 20,89 & 30,58 & 21,08 \\
\hline $\mathrm{MnO}$ & 0,83 & 0,44 & 0,39 & 0,00 & 0,38 \\
\hline $\mathrm{MgO}$ & 5,47 & 1,49 & 7,39 & 0,00 & 7,60 \\
\hline $\mathrm{CaO}$ & 0,00 & 0,04 & 0,00 & 0,01 & 0,01 \\
\hline $\mathrm{ZnO}$ & 0,27 & 0,00 & 0,18 & 0,03 & 0,19 \\
\hline celkem & 97,96 & 100,94 & 99,15 & 98,45 & 100,36 \\
\hline $\mathrm{Si}$ & 0,002 & 0,002 & 0,002 & 0,001 & 0,001 \\
\hline $\mathrm{Ti}$ & 0,004 & 0,000 & 0,001 & 0,001 & 0,003 \\
\hline $\mathrm{Al}$ & 0,238 & 0,000 & 0,230 & 0,000 & 0,261 \\
\hline $\mathrm{Cr}$ & 1,833 & 0,038 & 1,754 & 0,010 & 1,631 \\
\hline $\mathrm{V}$ & 0,000 & 0,024 & 0,001 & 0,001 & 0,002 \\
\hline $\mathrm{Ni}$ & 0,000 & 0,024 & 0,001 & 0,001 & 0,002 \\
\hline $\mathrm{Fe} \mathrm{Fi}^{3+}$ & 0,000 & 1,956 & 0,002 & 1,984 & 0,094 \\
\hline $\mathrm{Fe}{ }^{2+}$ & 0,593 & 0,879 & 0,604 & 1,000 & 0,601 \\
\hline $\mathrm{Mn}$ & 0,025 & 0,014 & 0,011 & 0,000 & 0,011 \\
\hline $\mathrm{Mg}$ & 0,289 & 0,084 & 0,381 & 0,000 & 0,386 \\
\hline $\mathrm{Ca}$ & 0,000 & 0,002 & 0,000 & 0,000 & 0,000 \\
\hline $\mathrm{Zn}$ & 0,007 & 0,000 & 0,004 & 0,001 & 0,005 \\
\hline celkem & 2,992 & 3,024 & 2,992 & 3,000 & 2,997 \\
\hline $\mathrm{Fe} / \mathrm{Fe}+\mathrm{Mg}$ & 0,67 & 0,97 & 0,61 & 1,00 & 0,64 \\
\hline $\mathrm{Cr} / \mathrm{Cr}+\mathrm{Al}$ & 0,89 & 1,00 & 0,88 & 1,00 & 0,86 \\
\hline $\mathrm{Mg} / \mathrm{Mg}+\mathrm{Fe}{ }_{2}$ & 0,33 & 0,09 & 0,39 & 0,00 & 0,39 \\
\hline & & & & & \\
\hline
\end{tabular}

Tab. IV: Chemické složení amfibolu ve vzorku AU1 Tab. IV: Chemical composition of amphibole from sample AU1

\begin{tabular}{|c|c|c|c|}
\hline \multirow{2}{*}{$\begin{array}{l}\text { vzorek } \\
\text { název } \\
\end{array}$} & AU1 & AU1 & \multirow{2}{*}{$\begin{array}{c}\text { AU1 } \\
\text { pargasi }\end{array}$} \\
\hline & \multicolumn{2}{|c|}{ magneziohornblend } & \\
\hline $\mathrm{SiO}_{2}$ & 44,262 & 44,056 & 43,199 \\
\hline $\mathrm{TiO}_{2}$ & 0,618 & 1,184 & 2,453 \\
\hline $\mathrm{Al}_{2} \mathrm{O}_{3}$ & 11,91 & 11,266 & 11,139 \\
\hline $\mathrm{MnO}$ & 0,336 & 0,288 & 0,263 \\
\hline $\mathrm{FeO}$ & 14,266 & 11,992 & 14,431 \\
\hline $\mathrm{Fe}_{2} \mathrm{O}_{3}$ & 4,164 & 3,847 & 0,721 \\
\hline $\mathrm{MgO}$ & 10,097 & 11,694 & 11,307 \\
\hline $\mathrm{CaO}$ & 12,07 & 12,004 & 12,14 \\
\hline $\mathrm{Na}_{2} \mathrm{O}$ & 1,469 & 1,354 & 1,524 \\
\hline $\mathrm{K}_{2} \mathrm{O}$ & 0,49 & 0,784 & 1,087 \\
\hline $\mathrm{H}_{2} \mathrm{O}^{+}$ & 1,96 & 1,95 & 1,94 \\
\hline $\mathrm{F}$ & 0,102 & 0,14 & 0,125 \\
\hline $\mathrm{Cl}$ & 0,007 & 0,041 & 0,045 \\
\hline $\mathrm{O}=\mathrm{F}, \mathrm{Cl}$ (calc) & $-0,04$ & $-0,07$ & $-0,06$ \\
\hline celkem & 101,71 & 100,53 & 100,31 \\
\hline T-Si & 6,478 & 6,473 & 6,413 \\
\hline T-Al & 1,522 & 1,527 & 1,587 \\
\hline $\mathrm{C}-\mathrm{Ti}$ & 0,068 & 0,131 & 0,274 \\
\hline C-Al & 0,533 & 0,424 & 0,363 \\
\hline $\mathrm{C}-\mathrm{Fe}^{3+}$ & 0,459 & 0,426 & 0,081 \\
\hline $\mathrm{C}-\mathrm{Fe}^{2+}$ & 1,737 & 1,458 & 1,78 \\
\hline $\mathrm{C}-\mathrm{Mg}$ & 2,203 & 2,561 & 2,503 \\
\hline B-Mn ${ }^{2+}$ & 0,042 & 0,036 & 0,033 \\
\hline $\mathrm{B}-\mathrm{Fe}^{2+}$ & 0,008 & 0,016 & 0,011 \\
\hline $\mathrm{B}-\mathrm{Ca}$ & 1,893 & 1,89 & 1,931 \\
\hline B-Na & 0,057 & 0,059 & 0,025 \\
\hline A-Na & 0,36 & 0,327 & 0,414 \\
\hline A-K & 0,091 & 0,147 & 0,206 \\
\hline $\mathrm{O}$ & 22 & 22 & 22 \\
\hline $\mathrm{OH}$ & 1,951 & 1,925 & 1,93 \\
\hline $\mathrm{F}$ & 0,047 & 0,065 & 0,059 \\
\hline $\mathrm{Cl}$ & 0,002 & 0,01 & 0,011 \\
\hline celkem & 15,451 & 15,475 & 15,621 \\
\hline
\end{tabular}

